\title{
Lise Öğrencilerine Verilen Beslenme Eğitiminin Beslenme Alışkanlıkları, Beslenme Bilgi Düzeyi ve Fiziksel Aktivite Üzerine Etkisi
}

\author{
The Effect of Nutrition Education on Nutritional Habits, Nutritional Knowledge and Physical \\ Activity of High School Students
}

\section{Betül Sarıdağ Devran ${ }^{1}$, Mendane Saka²}

Geliş tarihi/Received: 18.06.2019 • Kabul tarihi/Accepted: 19.08.2019

\section{ÖZET}

Amaç: Bu araştırma, lise öğrencilerine verilen beslenme eğitiminin öğrencilerin beslenme alışkanlıkları, beslenme bilgisi ve fiziksel aktivite düzeyleri üzerindeki etkisini belirlemek amacı ile planlanmıştır.

Bireyler ve Yöntem: Araştırma, Özel Hürriyet Koleji’nde 2017-2018 eğitim öğretim yılı ders dönemine kayıtlı 14-17 yaş arası lise 2. sınıf öğrencileri üzerinde yürütülmüştür. Çalışmaya katılmayı kabul eden öğrencilere Ekim ve Kasım 2017 aylarında, ayda iki kez olacak şekilde toplamda 4 kez sağlıklı beslenme konusunda eğitim verilmiştir. Eğitim öncesi, sonrası ve 2 ay bekleme süresi sonunda öğrencilere beslenme alışkanlıkları, besin tüketim kayıtları (3 gün) ve fiziksel aktivite kayıtlarına ilişkin anket formları toplamda 3 kez uygulanmıştır.

Bulgular: Toplam enerjinin protein ve yağdan gelen oranları 2 ay bekleme sonrası artmış, karbonhidrattan gelen oranı azalmış, günlük kolesterol alımı ise eğitim ve 2 ay bekleme sonrası artmıştır $(\mathrm{p}<0.05)$. Türkiye Beslenme Rehberi’ne göre öğrencilerin eğitim öncesi, sonrası ve 2 ay bekleme sonrası günlük ortalama A vitamini, $E$ vitamini, niasin, $B_{12}$ ve $C$ vitamini ile sodyum ve fosfor alımının önerilerin üzerinde, tiamin ve folat ile potasyum, kalsiyum, magnezyum ve demir alımlarının önerilenin altında olduğu saptanmıştır. Eğitim öncesi döneme göre, öğrencilerin eğitim sonrası ve 2 ay bekleme sonrası ortalama beslenme bilgi puanlarının arttığı ( $\mathrm{p}<0.05)$ saptanmıştır. Öğrencilerin fiziksel aktivite düzeyinde ise eğitim öncesine göre eğitim sonu ve 2 ay bekleme sonrasında anlamlı bir değişiklik gözlenmemiştir ( $p>0.05)$.

Sonuç: Öğrencilere verilen beslenme eğitiminin, beslenme bilgi düzeyinde anlamlı bir artış sağladığı ancak beslenme alışkanlıkları üzerinde istenilen etkiyi sağlayamadığı tespit edilmiştir. Beslenme eğitiminin daha etkili olabilmesi ve davranış değişikliği sağlanabilmesi için verilecek eğitimlerin daha sık aralıklarla, tüm eğitim-öğrenim dönemine yayılarak tekrarlanmasının daha yararlı olacağı düşünülmektedir.

Anahtar kelimeler: Beslenme, beslenme eğitimi, adölesan dönemi

1. İletişim/Correspondence: Bingöl Üniversitesi, Sağllk Bilimleri Fakültesi, Beslenme ve Diyetetik Bölümü, Bingöl, Türkiye

E-posta: betulsaridag@hotmail.com • ๑ https://orcid.org/0000-0003-4580-1998
2. Başkent Üniversitesi, Sağllk Bilimleri Fakültesi, Beslenme ve Diyetetik Bölümü, Ankara, Türkiye (1) https://orcid.org/0000-0002-5516-426X 


\section{ABSTRACT}

Aim: The aim of this study was to determine the effect of nutrition education on nutritional habits, nutritional knowledge, and physical activity levels of high school students.

Subjects and Method: $2^{\text {nd }}$ grade high school students in Hurriyet Private College between 14-17 years of age were enrolled in this study during the 2017-2018 academic years. Nutrition education on healthy eating was given to students who agreed to participate in the study twice a month, and 4 times in total on October and November 2018. A questionnaire including dietary habits, food records (3-days) and physical activity records was administered at 3 times: before education, after education, and at 2 months post-education.

Results: The ratio of total energy from protein and fat increased, while the percentage of energy from carbohydrates decreased significantly at 2 months post-education $(\mathrm{p}<0.05)$. There was also an increase in daily cholesterol intake after education and 2 months post-education ( $\mathrm{p}<0.05)$. According to Turkish Nutrition Guide, daily intakes of vitamin A, vitamin E, vitamin C, vitamin $\mathrm{B}_{12}$ and niacin as well as mineral intakes including sodium and phosphorus were above the recommendations. However, thiamine, folate, potassium, calcium, magnesium and iron intakes were below the recommendations. Mean nutritional knowledge scores of the students increased significantly after education and at 2 months post-education $(p<0.05)$. Physical activity levels of students did not change significantly after nutrition education or at 2 months post-intervention $(\mathrm{p}>0.05)$.

Conclusion: There was a significant increase in nutritional knowledge levels of the students after nutrition education however it was not effective on nutritional habits. Nutrition education should be extended through the entire academic year and should be given more frequently in order to provide a more effective education as well as to ensure behavioral change.

Keywords: Nutrition, nutrition education, adolescence.

\section{GİRIŞ}

Sağlıklı beslenmenin hedefi, yeterli ve dengeli beslenmenin sağlanmasıdır (1). Yeterli ve dengeli beslenme için diyette besin çeşitliliğinin sağlanması şarttır. Sağlıklı beslenme alışkanlığının küçük yaşlardan itibaren kişilere kazandırılması, besin çeşitliliğini sağlamakla birlikte aşırı şeker, yağ ve tuz içeren besinlerin tüketimini azaltmakta ve kronik hastalıklara yakalanma riskini düşürmektedir (1).

Sağlıklı beslenme alışkanlıklarının adölesan döneminde biçimlendirilmesi, çocukluk çağından başlayarak süre gelen beslenme eğitimi ile sağlanabilir $(2,3)$. Okullar, çocuk ve adölesanların beslenme durumlarını değerlendirmek ve beslenme eğitimi vermek için en uygun ortamlardır. Bu yaş grubu, zamanlarının büyük kısmını okulda geçirdikleri ve en az bir öğünlerini okulda tükettikleri için, okulda sağlıklı beslenme alışkanlıkları kazanabilirler. Okullarda verilen beslenme eğitim programları, büyüme, gelişme ve öğrenmeyi olumlu yönde etkilemenin yanı sıra, yetişkin dönemde şişmanlık, koroner kalp hastalığı, diyabet, kanser gibi kronik hastalıklara yakalanma riskinin de azalmasını sağlar. Kısacası, okul ortamı yeterli ve dengeli beslenme alışkanlıkları kazandırmada kısa ve uzun sürede ortaya çıkabilecek hastalıkların önlemesi için gerekli bilgi, yetenek ve davranışların gelişmesinde önemli bir konuma sahiptir $(4,5)$.

Çocukluk ve genç erişkinlik dönemi fiziksel aktivite alışkanlığının kazandırılması ve yaşam boyu devam ettirilmesi için en uygun dönemdir. Genç yaşta edinilen hareketsiz bir yaşam ve kötü beslenme alışkanlıklarını daha sonraki dönemlerde değiştirmek oldukça zordur (6). Bu çalışma, Bingöl ilinde özel bir eğitim kurumundaki lise öğrencilerinin mevcut beslenme alışkanlıklarını belirlemek ve bu öğrencilere belirli aralıklarla verilen sağlıklı beslenme eğitimlerinin öğrencilerin beslenme bilgi düzeyleri, beslenme alışkanlıkları ile fiziksel aktivite düzeyleri üzerindeki etkisini saptanmak amacıyla planlanmış ve yürütülmüştür. 


\section{BİREYLER VE YÖNTEM}

Bu çalışma, kesitsel ve yarı deneysel bir çalışma olarak planlanmış ve 2017-2018 eğitim-öğretim döneminin 1. ve 2. yarıyllında (Ekim-Kasım 2017, Şubat 2018) Bingöl il merkezinde bulunan Özel Hürriyet Eğitim Kurumları'nda yürütülmüştür. Çalışma için Başkent Üniversitesi Girişimsel Olmayan Klinik Araştırmalar Etik Kurulu'ndan 27/09/2017 tarih ve 17/77 Karar sayılı "Etik Kurul Onayı" ile Özel Hürriyet Eğitim Kurumları'ndan izin alınmış, ayrıca çalışmaya başlamadan önce öğrenci ve ebeveynlere çalışma hakkında bilgi verilerek, araştırmaya katılmayı kabul eden öğrencilere “Gönüllü Olur Formu” okutulup imzalatılmıştır.

Bingöl Hürriyet Eğitim Kurumları bünyesinde Anadolu ve Fen Liseleri'nin ikişer şubesi bulunmaktadır. Araştırmaya Anadolu Lisesi A ve B şubelerinden 20'şer öğrenci; Fen Lisesi'nden ise 21 (A şubesinden 10 ve B şubesinden 11) öğrenci olmak üzere toplam 61 öğrenci ile başlanmıştır. Hastalık ya da öğrencilerin araştırmaya devam etmek istememeleri nedeniyle araştırma 56 öğrenci ile tamamlanmıştır.

Çalışmaya katılmayı kabul eden öğrencilere gruplar halinde 2017 yllında Ekim ve Kasım aylarında ayda iki kez olacak şekilde toplamda 4 kez sağlıklı beslenme konusunda eğitim verilmiştir. Eğitim süresi her eğitim seansında 20 dakika beslenme eğitimi, 40 dakika soru-cevap olacak şekilde (toplam 60 dakika) planlanmıştır. Eğitim konuları sağlıklı beslenme, adölesan beslenmesi ve sık sorulan güncel sorular olarak belirlenmiş olup, tüm eğitimler interaktif olarak yapılmış ve bilgisayarda hazırlanan sunumlar ile desteklenmiştir.

Öğrencilerin sosyo-demografik özellikleri, beslenme alışkanlıkları, fiziksel aktivite ve antropometrik ölçümlerini içeren anket formları eğitim öncesi, sonrası (2017 yılı Ekim ve Kasım ayları) ve eğitimin kalıcılığını ölçmek için 2 ay bekleme sonrasında (2018 yılı Şubat ayı) öğrencilere uygulanmış olup, toplam araştırma süresi 5 ay olarak belirlenmiştir.

\section{Beslenme Bilgi Testinin Uygulanması}

Öğrencilerin beslenme bilgi düzeylerini belirlemek için temel beslenme bilgilerini içeren "Beslenme Bilgi Testi” eğitim öncesi, sonrası ve 2 ay bekleme sonrası uygulanmıştır. Her eğitimin konu başlığı ve içeriği birbirinden farklı olup eğitim öncesinde ve sonrasinda uygulanan "Beslenme Bilgi Testi” soruları aynıdır. Beslenme Bilgi Testi, araştırmacıların kendisi tarafından, öğrencilere verilen beslenme eğitiminin içeriğine yönelik hazırlanmış toplam 15 sorudan oluşturulmuştur. Değerlendirme sırasında her doğru soru bir puan olarak değerlendirilmiş ve toplam skora göre öğrencilerin beslenme bilgi düzeyleri “discriminant” analizi ile bir istatistikçi tarafından hesaplanmıştır. Eğitim öncesi, sonrası ortalama bilgi puanları oransal olarak karşılaştırılarak eğitimin etkisi ve kalıcılığı değerlendirilmiştir.

\section{Besin Tüketim Kaydının Alınması}

Öğrencilerin besin tüketim durumlarını belirlemek için besin tüketim kayıt formu eğitim öncesi, sonrası ve 2 ay bekleme süresi sonunda uygulanmıştır. Öğrencilerden besin tüketim kayıt formunu 3 gün (birbirini izleyen ve bir günü hafta içi, iki günü hafta sonu) süre ile doldurmaları istenmiştir. Besin tüketim kayıtlarından elde edilen veriler "Beslenme Bilgi Sistemleri Programı” (BEBİs, versiyon 8.1) ve Türkiye Beslenme Rehberi'ne göre (TÜBER) analiz edilmiştir (1).

\section{Uluslararası Fiziksel Aktivite Formu}

Öğrencilerin fiziksel aktivite düzeylerini belirlemek için geçerlilik ve güvenilirlik çalışması yapılmış olan Uluslararası Fiziksel Aktivite Kısa Formu (International Physical Activity Questionnaire [IPAQ]) (7) kullanılmış; form eğitim öncesi, sonrası ve 2 ay bekleme sonrası olmak üzere toplamda 3 kez uygulanmıştır. IPAQ'da fiziksel aktivitelerin, tek seferde en az 10 dakika yapılıyor olması ölçüt alınmıştır. Anket ile son 7 gün içerisinde (8): 
- Şiddetli fiziksel aktivite (futbol, basketbol, aerobik, hızlı bisiklet çevirme, ağırlık kaldırma, yük taşıma vb.) süresi (dakika),

- Orta dereceli fiziksel aktivite (hafif yük taşıma, normal hızda bisiklet çevirme, halk oyunları, dans, bowling, masa tenisi vb.) süresi (dakika),

- Yürüme ve bir günlük oturma süreleri (dakika) sorgulanmıştır.

Şiddetli, orta dereceli aktivite ve yürüme süreleri aşağıdaki hesaplamalarla bazal metabolik hıza karşıllk gelen metabolik eşdeğer (MET)'e çevrilerek toplam fiziksel aktivite skoru (MET-dakika/hafta) hesaplanmıştır:

- Yürüme skoru (MET-dakika/hafta) = 3.3 x Yürüme süresi x Yürüme günü,

- Orta şiddetli aktivite skoru (MET-dakika/hafta) = $4.0 \times$ Orta şiddetli aktivite süresi $\times$ Orta şiddetli aktivite günü,

- Şiddetli aktivite skoru (MET-dakika/hafta) $=8.0$ $\times$ Şiddetli aktivite süresi $\times$ Şiddetli aktivite günü,

- Toplam Fiziksel Aktivite skoru (MET-dakika/ hafta) = Yürüme + Orta şiddetli aktivite + Şiddetli aktivite skorları

Toplam fiziksel aktivite skoruna göre katılımcıların fiziksel aktivite düzeyleri "düşük, orta ve yüksek" biçiminde sınıflandırılmıştır:

1. Düşük düzey <600 MET-dakika/hafta,

2. Orta düzey 600-3000 MET-dakika/hafta,

3. Yüksek düzey $>3000$ MET-dakika/hafta olarak değerlendirilmiştir (7).

\section{Verilerin İstatistiksel Değerlendirmesi}

Çalışmadan elde edilen veriler SPSS İstatistik Paket Programı (SPSS, versiyon 22.0) kullanılarak değerlendirilmiştir. Kolmogorov Smirnov testine göre veriler analiz edilmiş ve normal dağılım göstermediği saptanmıştır. Parametrik koşulların sağlanamamıs olması nedeniyle iki ve ikiden fazla grup ortalamalarının karşılaştırılmasında sırasıyla Kruskal Wallis ve Mann-Whitney U testleri kullanılmıştır. Tekrarlayan ölçümlerin karşılaştırılması Friedman ve Cochrans' Q testleri ile yapılmıştır. Tüm istatistiksel testlerde en düşük önemlilik düzeyi $\mathrm{p}<0.05$ olarak alınmıştır.

\section{BULGULAR}

Öğrencilerin eğitim öncesi, sonrası ve eğitimden 2 ay sonrasındaki beslenme alışkanlıklarına göre dağılımı Tablo 1'de verilmiştir. Öğrencilerin eğitim öncesi, sonrası ve 2 ay bekleme sonrası öğün atlama durumları incelendiğinde en fazla atlanan öğünün kahvaltı olduğu ve verilen beslenme eğitiminin öğün atlama sıklığı üzerinde istatistiksel olarak anlamlı bir etki yapmadığı belirlenmiş̧ir ( $>0.05$ ).

Eğitim öncesinde en sık öğün atlama nedeni olarak 'isteksizlik' (\%53.6) gösterilirken, eğitim sonrası ve 2 ay bekleme sonrası bu oran azalarak yerini "zaman yetersizliğine” (\%44.6) bırakmıştır $(\mathrm{p}<0.05)$.

Öğrencilerin beslenme eğitimi öncesi ve sonrası günlük diyet ile aldıkları enerji ve makro besin ögelerinin ortalama miktarları Tablo 2' de gösterilmiştir. Öğrencilerin eğitim ve 2 ay bekleme sonrası enerji alım ortalamalarının azaldığı ancak farkın istatiksel olarak anlamlı olmadığı saptanmıştır ( $p>0.05)$. Öğrencilerin eğitim öncesi günlük ortalama yağ alımının eğitim ve 2 ay bekleme sonrasına göre yüksek olduğu saptanmıştır. Eğitim öncesi ve sonrası toplam enerjinin yağdan gelen oranının benzer olduğu, 2 ay bekleme sonunda bu oranın arttığ 1 bulunmuştur $(\mathrm{p}<0.05)$. Toplam enerjinin karbonhidrattan gelen oranı eğitim sonrası ve 2 ay bekleme sonunda azalmıştır $(\mathrm{p}<0.001)$.

Günlük diyet ile alınan vitaminlerin ortalama miktarları eğitim öncesi, sonrası ve 2 ay bekleme sonrası değerlendirildiğinde, öğrencilerin günlük ortalama tiamin, riboflavin, niasin, $\mathrm{B}_{6}, \mathrm{C}$ vitamini, folat ve pantotenik asit alımlarının eğitim ve 2 ay bekleme sonrasında azaldığı, sadece pantotenik 
Tablo 1. Öğrencilerin beslenme eğitimi öncesi ve sonrası öğün atlama durumlarının ve nedenlerinin değerlendirilmesi

\begin{tabular}{|c|c|c|c|c|c|c|c|}
\hline \multirow{2}{*}{ Öğün atlama durumları ve nedenleri } & \multicolumn{2}{|c|}{ Eğitim öncesi } & \multicolumn{2}{|c|}{ Eğitim sonrası } & \multicolumn{2}{|c|}{2 ay sonra } & \multirow{2}{*}{$p$} \\
\hline & $\mathrm{S}$ & $\%$ & S & $\%$ & $\mathrm{~S}$ & $\%$ & \\
\hline \multicolumn{8}{|l|}{ Öğünler† } \\
\hline Kahvaltı & 20 & 35.7 & 19 & 33.9 & 25 & 44.6 & 0.429 \\
\hline Öğle & 10 & 17.9 & 13 & 23.2 & 5 & 8.9 & \\
\hline Akşam & 6 & 10.7 & 4 & 7.1 & 5 & 8.9 & \\
\hline Ara & 20 & 35.7 & 20 & 35.7 & 21 & 37.6 & \\
\hline \multicolumn{8}{|l|}{ Öğün atlama nedeni } \\
\hline Zayıflamak için & 7 & 12.5 & 3 & 5.4 & 3 & 5.4 & $0.035^{*}$ \\
\hline Canı istemediği için & 30 & 53.6 & 28 & 50.0 & 21 & 37.5 & \\
\hline Unuttuğu için & 2 & 3.6 & 1 & 1.8 & 4 & 7.1 & \\
\hline Zaman yetersizliğinden & 10 & 17.9 & 15 & 26.8 & 25 & 44.6 & \\
\hline Üşendiği için & 7 & 12.5 & 9 & 16.1 & 3 & 5.4 & \\
\hline
\end{tabular}

Cochrans' $Q$ test, ${ }^{*} p<0.05$

Tablo 2. Öğrencilerin beslenme eğitimi öncesi ve sonrası günlük ortalama enerji ve makro besin ögesi alımları ve TÜBER’e göre karşılama yüzdeleri

\begin{tabular}{|c|c|c|c|c|c|c|c|c|}
\hline \multirow[b]{2}{*}{$\begin{array}{l}\text { Enerji ve makro } \\
\text { besin ögeleri }\end{array}$} & \multicolumn{2}{|c|}{ Eğitim öncesi } & \multicolumn{2}{|c|}{ Eğitim sonrası } & \multicolumn{2}{|c|}{2 ay sonrası } & \multirow[b]{2}{*}{$\boldsymbol{F}$} & \multirow[b]{2}{*}{$p$} \\
\hline & $\begin{array}{c}\overline{\mathrm{X}} \pm \mathrm{SS} \\
\text { (Alt-Üst) }\end{array}$ & $\begin{array}{c}\text { TÜBER } \\
\text { (\%) }\end{array}$ & $\begin{array}{c}\overline{\mathrm{X}} \pm \mathrm{SS} \\
\text { (Alt-Üst) }\end{array}$ & $\begin{array}{c}\text { TÜBER } \\
\text { (\%) }\end{array}$ & $\begin{array}{c}\overline{\mathrm{X}} \pm \mathrm{SS} \\
\text { (Alt-Üst) }\end{array}$ & $\begin{array}{c}\text { TÜBER } \\
\text { (\%) }\end{array}$ & & \\
\hline Enerji (kkal) & $\begin{array}{c}2211.3 \pm 417.8 \\
(1414.9-3368.3)\end{array}$ & & $\begin{array}{c}2125.4 \pm 439.0 \\
(1403.4-3241.2)\end{array}$ & & $\begin{array}{c}2070.6 \pm 379.6 \\
(305.5-1562.0)\end{array}$ & & 1.653 & 0.195 \\
\hline Protein (g) & $\begin{array}{c}73.4 \pm 14.2 \\
(47.6-104.0)\end{array}$ & 120.5 & $\begin{array}{c}69.7 \pm 15.3 \\
(37.8-103.6)\end{array}$ & 114.4 & $\begin{array}{c}72.7 \pm 13.7 \\
(44.9-108.9)\end{array}$ & 119.2 & 1.036 & 0.357 \\
\hline Protein (\% E) & $\begin{array}{c}13.4 \pm 1.8 \\
(10.1-17.4)\end{array}$ & & $\begin{array}{l}13.2 \pm 1.8 \\
(9.6-18.7)\end{array}$ & & $\begin{array}{l}14.1 \pm 1.5^{*} \\
(10.9-17.4)\end{array}$ & & 12.242 & 0.002 \\
\hline Yağ (g) & $\begin{array}{c}103.0 \pm 22.4 \\
(56.9-146.8)\end{array}$ & & $\begin{array}{c}100.3 \pm 22.8 \\
(58.8-156.4)\end{array}$ & & $\begin{array}{c}101.7 \pm 18.7 \\
(69.0-148.3)\end{array}$ & & 0.225 & 0.798 \\
\hline Yağ (\%E) & $\begin{array}{c}41.9 \pm 4.9 \\
(30.3-54.9)\end{array}$ & & $\begin{array}{c}42.4 \pm 3.7 \\
(34.6-49.6)\end{array}$ & & $\begin{array}{c}44.4 \pm 4.1^{*} \\
(35.4-52.9)\end{array}$ & & 8.482 & 0.014 \\
\hline Doymuş YA (\% E) & $\begin{array}{l}12.7 \pm 2.7 \\
(8.8-21.5)\end{array}$ & & $\begin{array}{l}12.4 \pm 2.1 \\
(9.4-19.1)\end{array}$ & & $\begin{array}{l}13.1 \pm 2.0 \\
(9.5-17.7)\end{array}$ & & 3.090 & 0.213 \\
\hline TDYA (\% E) & $\begin{array}{c}13.9 \pm 2.2 \\
(10.0-19.4)\end{array}$ & & $\begin{array}{c}13.7 \pm 1.8 \\
(10.7-18.7)\end{array}$ & & $\begin{array}{c}14.6 \pm 1.9 \\
(10.6-18.2)\end{array}$ & & 5.844 & 0.054 \\
\hline ÇDYA (\% E) & $\begin{array}{l}11.3 \pm 2.9 \\
(5.5-11.3)\end{array}$ & & $\begin{array}{c}12.2 \pm 2.3 \\
(7.6-16.9)\end{array}$ & & $\begin{array}{c}12.2 \pm 2.1 \\
(7.7-16.6)\end{array}$ & & 4.558 & 0.102 \\
\hline Kolesterol (mg) & $\begin{array}{l}264.4 \pm 115.5 \\
(79.2-642.3)\end{array}$ & & $\begin{array}{l}275.8 \pm 103.0 \\
(82.3-500.4)\end{array}$ & & $\begin{array}{c}312.1 \pm 80.4^{*} \\
(131.3-523.4)\end{array}$ & & 9.716 & 0.007 \\
\hline Karbonhidrat (g) & $\begin{array}{c}243.6 \pm 55.8 \\
(115.9-433.9)\end{array}$ & & $\begin{array}{c}231.8 \pm 53.3 \\
(133.7-402.4)\end{array}$ & & $\begin{array}{c}212.3 \pm 50.7^{*} \\
(144.2-369.0)\end{array}$ & & 4.911 & 0.008 \\
\hline Karbonhidrat (\% E) & $\begin{array}{c}43.9 \pm 4.5 \\
(30.8-55.4)\end{array}$ & & $\begin{array}{c}43.6 \pm 3.9 \\
(35.6-49.6)\end{array}$ & & $\begin{array}{c}40.8 \pm 4.0 \\
(30.9-48.9)\end{array}$ & & 16.789 & 0.000 \\
\hline Posa (g) & $\begin{array}{c}20.0 \pm 5.4 \\
(10.2-40.5) \\
\end{array}$ & 95.23 & $\begin{array}{c}20.8 \pm 5.3 \\
(13.2-32.4) \\
\end{array}$ & 98.95 & $\begin{array}{c}19.3 \pm 4.2 \\
(12.1-35.1) \\
\end{array}$ & 92.09 & 2.059 & 0.131 \\
\hline
\end{tabular}

YA: Yağ asitleri, ÇDYA: Çoklu doymamış yağ asitleri, TDYA: Tekli doymamış yağ asitleri, \%E: Enerjinin makro besin ögesinden gelen oranı, TÜBER: Türkiye Beslenme Rehberi. 
asitteki azalmanın anlamlı olduğu bulunmuştur $(p<0.05)$. A vitamini, E vitamini, niasin, $B_{12}$ ve $C$ vitamini alımlarının TÜBER önerilerinin üzerinde, tiamin ve folat alımlarının ise istatistiksel olarak anlamlı olmasa da önerilerin altında olduğu ve eğitim öncesi-sonrası dönemler arasında karşılama oranlarının benzer olduğu görülmüştür $(p>0.05)$ (veri tabloda gösterilmemiştir).

Öğrencilerin eğitim öncesi, sonrası ve 2 ay bekleme sonrası günlük eser element ve mineral alımlarının ortalama miktarları değerlendirildiğinde, sodyum, potasyum, kalsiyum, fosfor ve demirin günlük ortalama alımlarının eğitim öncesine göre eğitim sonrası ve 2 ay bekleme sonunda giderek azaldığı ancak farkın anlamlı olmadığı bulunmuştur ( $p>0.05)$. Öğrencilerin eğitim öncesi, sonrası ve 2 ay bekleme sonrası TÜBER'de ortalama sodyum ve fosfor alımlarının önerilerin üzerinde olduğu, potasyum, kalsiyum, magnezyum ve demir alımlarının ise önerilerin altında olduğu saptanmıştır (veri tabloda gösterilmemiştir).

Tablo 3’te öğrencilere verilen beslenme eğitiminin ortalama beslenme bilgi puanı üzerine etkisi incelenmiş ve bağımlı gruplarda üç farklı ölçüm ortalaması karşılaştırması sonucu eğitim sonrası bilgi puan ortalamasinın $7.1 \pm 2.3$ 'ten $8.6 \pm 2.8$ 'e ve 2 ay bekleme sonrasında $9.9 \pm 3.1$ 'e çıktığı saptanmıştır. İki ay bekleme sonrasındaki bilgi puanı farkının istatistiksel olarak anlamlı olduğu tespit dilmiştir $(\mathrm{p}=0.000)$.

Tablo 3. Öğrencilere verilen beslenme eğitiminin ortalama beslenme bilgi puanı üzerine etkisinin değerlendirilmesi

\begin{tabular}{lcc}
\hline Bilgi testi & Bilgi puanı $\overline{\mathrm{X}}_{ \pm} \mathbf{S S}$ & $\mathbf{p}$ \\
\hline Eğitim öncesi & $7.1 \pm 2.3$ & \\
Eğitim sonrası & $8.6 \pm 2.8$ & $0.000^{*}$ \\
2 ay sonrası & $9.9 \pm 3.1$ & \\
\hline
\end{tabular}

Friedman test, ${ }^{*} p<0.005$

Eğitim öncesi öğrencilerin \%51.8’inin düşük düzey, 2 ay bekleme sonunda ise çoğunluğun (\%51.8) yüksek düzey aktivite yaptığı görülmüştür (Tablo 4). Yüksek ve orta düzey fiziksel aktivite yapan öğrencilerin oranında 2 ay bekleme sonrasında artış olduğu ancak bu farkın anlamlı olmadığı gözlemlenmiştir ( $p>0.05$ ).

\section{TARTIŞMA}

Sağlıklı beslenme alışkanlıkları, doğru besin tercihi ve sağlıklı bir şekilde yaşamın sürdürülmesi için bireylerin yeterli düzeyde beslenme bilgisine sahip olmaları gerekmektedir. Beslenme bilgisi beslenme eğitiminin verilmesi ile sağlanır. Sağlıklı yaşam alışkanlıklarının adölesan dönemde biçimlendirilmesi, çocukluk çağında süregelen beslenme eğitimi ile sağlanabilir. Okullar, çocuk ve adölesanların beslenme durumlarını değerlendirmek ve beslenme eğitimi vermek için en uygun ortamlardır (3-5).

Sağlıklı ve dengeli beslenmenin gün içerisinde sağlanmasında öğünler ve öğün örüntüleri büyük öneme sahiptir. Günlük tüketilmesi gereken besinleri üç ana öğünde tüketerek metabolizmanın sağlıklı ve dengeli bir düzende çalışması sağlanabilir (1). Türk ve ark. (9)'nın yaptıkları bir çalışmada lise öğrencilerinin \%81'inin öğün atladığı ve en sık atlanan öğünün kahvaltı olduğu belirtilmiştir. Ögün atlama nedenleri arasında ilk iki sırada iştahsızlık ve zaman darlığı seçeneklerini belirttikleri tespit edilmiştir. Bir başka çalışmada, erkek öğrencilerin çoğunluğunun sabah, kız öğrencilerin ise öğle öğününü atladıkları ve atlama nedeni olarak en sık "isteksizlik" seçeneğini bildirdikleri saptanmıştır (10). Türkiye genelinde ise 15-18 yaş adölesanların \%71.7'sinin 3 ana öğün tükettiği, en çok atlanan öğünün kahvaltı öğünü olduğu (\%21.0) rapor edilmiştir (11). Bu çalışmada, öğrencilerin eğitim öncesi, sonu ve 2 ay bekleme sonrasında öğün atlama durumları incelendiğinde en fazla atlanan öğünün kahvaltı olduğu saptanmış ancak verilen beslenme eğitiminin öğrencilerin öğün tüketim alışkanlıkları üzerinde istenilen olumlu etkiyi sağlamadığı belirlenmiştir. Öğrenciler öğün atlama nedeni olarak eğitim öncesi ve sonrasında en sık "isteksizlik" seçeneğini bildirirken, 2 ay bekleme sonrası çoğunluğunun "zaman yetersizliğinden" 
Tablo 4. Öğrencilerin beslenme eğitimi öncesi ve sonrası fiziksel aktivite yapma durumlarının IPAQ’a göre değerlendirilmesi

\begin{tabular}{lcccccccc}
\hline Aktivite düzeyi & \multicolumn{2}{c}{ Eğitim öncesi } & \multicolumn{2}{c}{ Eğitim sonrası } & \multicolumn{2}{c}{ 2 ay sonra } & \multirow{2}{*}{$\boldsymbol{X}^{2}$} & \multirow{2}{*}{$\boldsymbol{p}$} \\
\cline { 2 - 6 } (IPAQ) & $\mathbf{S}$ & $\mathbf{\%}$ & $\mathbf{S}$ & $\mathbf{\%}$ & $\mathbf{S}$ & $\mathbf{\%}$ & & \\
\hline Düşük düzey & 29 & 51.8 & 28 & 50.0 & - & - & \multirow{2}{*}{0.481} \\
Orta düzey & 17 & 30.4 & 16 & 28.6 & 27 & 48.2 & \multirow{2}{*}{1.463} & 0.48 \\
Yüksek düzey & 10 & 17.8 & 12 & 21.4 & 29 & 51.8 & &
\end{tabular}

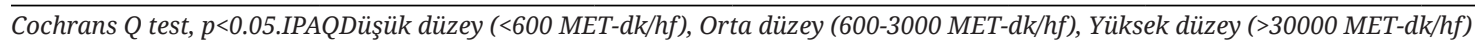

IPAQ: Uluslararası Fiziksel Aktivite Formu (International Physical Activity Questionnaire)

kahvaltı yapmadıklarını bildirdikleri görülmüştür $(p<0.05)$. Öğün atlama nedenlerine bakıldığında kahvaltı ve öğle öğünü için çoğunlukla "canı istemiyor”, akşam öğünü için ise "atıştırdığı için” nedenlerinin gösterildiği belirlenmiştir. Çalışmalar (911) incelendiğinde öğrenciler arasında en çok atlanan öğünün kahvaltı öğünü olduğu ve atlama nedeni olarak da en çok "canı istemediği” için seçeneğinin belirtildiği görülmektedir. Bu çalışmada, beslenme eğitiminin öğün atlama üzerinde olumlu bir etki sağlayamaması, bu yaş grubundaki gençlere verilecek olan eğitimlerin davranış haline dönüşmesi için daha sık aralıklarla ve daha uzun süre ile verilmesi gerektiğine işaret etmektedir.

Öğrencilerin günlük ortalama enerji alımları incelendiğinde, beslenme eğitimi sonrası ve 2 ay bekleme süresinin sonunda ortalama enerji alımlarının benzer şekilde zamanla azaldığı saptanmıştır. Türkiye genelinde 15-18 yaş grubunda erkek adölesanların günlük diyet ile ortalama 2288 kkal, kızların 1701 kkal enerji aldığı tespit edilmiştir (11). Baş ve ark. (12)'nın yaptıkları çalışmada 12-19 yaş grubu erkeklerin günlük ortalama 1,964 kkal, kızların ise 1,804 kkal enerji aldığı belirlenmiştir. $\mathrm{Bu}$ çalışmadaki öğrencilere verilen beslenme eğitiminin günlük ortalama enerji alımları üzerine olumlu etki sağlamadığı tespit edilmiş, eğitimlerin etkili olabilmesi için daha uzun süreli sık aralıklarla verilmesi gerektiği düşünülmüştür.

Türkiye genelinde 15-18 yaş grubundaki erkeklerin günlük ortalama $68 \mathrm{~g}$, kız çocukların $48.8 \mathrm{~g}$ protein aldıkları bulunmuştur (11). Aslan ve ark. (10)'nın yaptıkları çalışmada öğrencilerin günlük ortalama 64.7 g protein aldıkları belirlenmiştir. Bu çalışmadaki öğrencilerin eğitim öncesi, sonrası ve 2 ay bekleme sonrası TÜBER'e göre ortalama protein alımlarının yüksek olduğu tespit edilmiştir. Aslan ve ark. (10)'nın çalışma bulguları, TBSA 2010 verileri (11) ve TÜBER önerileri değerlendirildiğinde (1) bu çalışmadaki öğrencilerin ortalama protein alımlarının yüksek olduğu bulunmuş ve öğrencilerin günlük ortalama protein alımları üzerine beslenme eğitimi ve bekleme süresinin anlamlı bir etkisinin olmadığı belirlenmiştir ( $p>0.05)$.

Türkiye genelinde 15-18 yaş grubunda erkeklerin günlük ortalama yağ alımlarının $85.1 \mathrm{~g}$, kızların günlük ortalama $65.1 \mathrm{~g}$ olduğu görülmüştür (11). TBSA 2010 verilerine göre toplam enerjinin yağdan gelen oranının 15-18 yaş grubu erkeklerde \%32.7, kızlarda \%34.3 olduğu bildirilmiştir (11). Bu çalışmada yer alan öğrencilerin günlük diyetle ortalama doymuş, doymamış yağ ve toplam yağ alımları ile 2 ay bekleme sonrası ortalama kolesterol alım miktarlarının önerilerin üzerinde olduğu tespit edilmiştir (1). Diyette fazla miktarda toplam yağ alımı başta kalp ve damar hastalıkları, diyabet, obezite ve kanser gibi hastalıklar olmak üzere beslenme ile ilintili bulaşıcı olmayan pek çok hastalığa neden olmaktadır (1). Öğrencilerin yağ tüketim miktarlarının yüksek olması yüksek enerjili kızartılmıs yiyeceklerin, cips, fast-food, simitpoğaça gibi hamur işlerinin fazla tüketilmesinden kaynaklandığı düşünülebilir. Adölesan dönemdeki gençlerin beslenme alışkanlıkları arkadaş, medya, internet gibi pek çok etkenden etkilenmektedir. Bu dönemde edinilen beslenme alışkanlıkları genellikle hızlı-hazır, ucuz, yağ ve enerji içeriği yüksek besin seçimlerine dayalıdır. Dolayısıyla bu yaş grubu gençlere sağlıklı beslenme alışkanlığı kazandırmak 
için aile ve arkadaş çevresinin de dahil olduğu beslenme eğitimlerinin okul programları içerisinde ele alınması ve eğitimde sürekliliğinin sağlanması gerekmektedir.

Öğrencilerin karbonhidrat alımları incelendiğinde TBSA 2010 verileri ve önerilerin altında olduğu, beslenme eğitiminin günlük ortalama karbonhidrat alımı üzerine olumlu bir etkisinin olmadığı belirlenmiştir. Öğrenciler arasında karbonhidrat tüketiminin düşük olmasının nedeni ekmek, pirinç, makarna, bulgur gibi karbonhidrattan zengin besinlerin şişmanlatacağı korkusuyla daha az tüketilmesinden kaynaklandığı ve bu düşüncelerinin televizyon, arkadaş ve internet ortamındaki bilgi kirliliğiyle alışkanlık haline geldiği düşünülmektedir. Briggs et al. (13)'un çalışmasında adölesan öğrencilerin diyetle günlük ortalama 2243 kkal enerji aldıkları, aldıkları enerjinin karbonhidrattan gelen oranınin \%55.0, proteinden gelen oraninin $\% 16.0$ ve yağdan gelen oranının ise \%29.0 olduğu belirtilmiştir. $\mathrm{Bu}$ çalışma, Briggs et et al. (13)'un yaptığı çalışma ile kıyaslandığında, günlük alınan toplam enerjinin benzer olduğu, toplam enerjinin karbonhidrat ve proteinden gelen yüzdelerinin düşük, yağın ise yüksek olduğu belirlenmiştir. $\mathrm{Bu}$ çalışmada öğrencilere verilen beslenme eğitiminin enerji ve makro besin ögeleri alımı üzerinde etkili olmaması, eğitim süresinin iki ay ile sinırlı olmasından kaynaklandığı düşünülmüş ve beslenme eğitiminin bir kazanıma dönüşebilmesi için eğitimin sürekli ve sık aralıklarla verilmesi gerektiği düşünülmüştür.

Diyet posasının divertikül, kabızlık, hemoroit, kolon kanseri, şişmanlık, diyabet ve kalp damar hastalıklarına karşı koruyucu etkisi kesin olarak bilinmektedir (14). Türkiye genelinde 15-18 yaş grubu erkeklerin 23.2 g, kızların günlük ortalama 18.9 g posa aldıkları görülmüştür (11). Gümüş ve ark. (15)'nın yaptıkları bir çalışmada, 13-18 yaş grubu adölesanların günlük $18.5 \mathrm{~g}$ posa aldıkları belirtilmiştir. $\mathrm{Bu}$ araştırmadaki öğrencilerin günlük ortalama posa alımlarının TÜBER'e göre karşılama oranı eğitim öncesi, sonrası ve 2 ay bekleme sonrası sırasıyla \%95.2, $\% 98.9$ ve $\% 92.1$ olduğu bulunmuş, günlük ortalama posa alımlarının TBSA 2010 verilerine benzer, Gümüş ve ark. (15)'nın verilerinden yüksek ancak eğitimden bağımsız bir şekilde önerilerin altında olduğu tespit edilmiştir. Öğrencilerin posa tüketimlerinin istenilen düzeyde olmaması öğrencilerin günlük diyetleri ile posadan zengin tahıl, kurubaklagil, sebze ve meyve grubuna yeterince yer vermemesinden kaynaklandığ düşünülmektedir. İki ay bekleme sonrasında posa alımındaki düşüş ise eğitimlerin daha uzun süre devam etmesi gerekliliğini ortaya koyabilir.

Araştırmadaki öğrencilerin günlük vitamin alımlarının TÜBER'e göre karşılama oranları incelendiğinde A vitamini, riboflavin, niasin, $B_{12}$, $C$ ve $E$ vitaminlerinin önerilerin üzerinde, tiamin ve folat vitaminlerinin önerilerin altında ve $\mathrm{B}_{6}$ ile pantotenik asit alımlarının önerilen değer kadar olduğu tespit edilmiştir. Öğrencilerin eğitim ve 2 ay bekleme sonrasındaki günlük ortalama pantotenik asit alımları dışında diğer vitaminlerdeki farklılıkların anlamlı olmadığı tespit edilmiştir ( $\mathrm{p}=0.039)$.

Öğrencilerin günlük mineral alımlarının TÜBER'e göre karşılama oranları incelendiğinde, sodyum ve fosfor minerallerinin önerilerin üzerinde, potasyum, kalsiyum, magnezyum, demir, çinko minerallerinin önerilerin altında alındığı saptanmıştır. Bu çalışmaya benzer olarak İspanya'da yaşayan çocuk ve ergenler üzerinde yürütülmüş bir çalışmada folat, magnezyum ve kalsiyum alımlarının yetersiz olduğu, sodyum alımının yüksek olduğu ve yaş ile birlikte alımın arttığı saptanmıştır (16). Bu çalışmada verilmiş olan beslenme eğitiminin öğrencilerin vitamin ve mineral alımları üzerinde istenilen etkiyi sağlamadığı, bu durumun eğitim süresinin 2 ay yerine tüm eğitim öğretim dönemini kapsayacak şekilde olması gerektiğini düşündürmektedir.

Sağlıklı yemek yeme alışkanlıkları, doğru besin tercihi ve sağlıklı bir şekilde yaşamın sürdürülmesi için bireylerin yeterli düzeyde beslenme bilgisine sahip olmaları gereklidir. Beslenme bilgisinin kazanımı ise beslenme eğitimi ile olmaktadır. Beslenme eğitim programlarının beslenme bilgisi ve diyet davranışları üzerinde direkt etkili olduğu bilinmektedir (17). 
$\mathrm{Bu}$ çalışmada 4 hafta süresince verilen beslenme eğitiminin öğrencilerin beslenme bilgi düzeyi üzerine etkisi incelendiğinde eğitim ve 2 ay bekleme sonrası bilgi puan ortalamasının arttığı tespit edilmiştir (2 ay sonrası $\mathrm{p}<0.05$ ). Viggiano et al. (18)'un çalışmasında 3110 çocuk ve adölesanın beslenme eğitimini desteklemek ve beslenme davranışını iyileştirmek için bir masa oyunu geliştirilip uygulanmıştır. Altı ayın sonunda masa oyunu ile beslenme bilgisinin ve beslenme davranışlarının düzeldiği ve BKİ üzerinde sürekli bir etkiye sahip olduğu, dolayısıyla çocukluk ve adölesan dönemde sağlıklı beslenme alışkanlığının kazanılmasında oyunun etkili bir eğitim aracı olduğu tespit edilmiştir.

Çocukluk ve erişkinlik dönemleri arasındaki biyolojik, fizyolojik ve bilişsel dönem olan adölesan dönemde fiziksel uygunluk düzeyinin belirlenmesinin sağlıklı bireylerin yetişmesi açısından önemli bir yeri vardır (19). Fiziksel aktivite, fizyolojik, metabolik, psikolojik parametrelerin iyileştirilmesinde, birçok kronik hastalık ve erken mortalite riskinin azaltılmasında, kan basıncının düzenlenmesinde, obezitenin engellenmesinde, kemik, kas ve eklem sağlı̆̆ının sürdürülmesinde yardımcıdır (19,20). Dmitruk et al. (21)'un çalışmasında kızların \%70'inin, erkeklerin \%69.2'sinin yüksek düzey fiziksel aktivite yaptığı, Tsioufis et al. (22)'un çalışmasında ise öğrencilerin \%7.8'inin düşük, \%46.3'ünün orta ve \%46.6'sinin yüksek düzey fiziksel aktivite yaptığı saptanmıştır. $\mathrm{Bu}$ çalışma diğer 2 çalışma ile kıyaslandığında öğrencilerin eğitim öncesi daha düşük fiziksel aktivite düzeyine sahip olduğu ancak eğitim ve 2 ay bekleme sonrası öğrencilerin fiziksel aktivite düzeylerinin arttığı belirlenmiştir. Bu durumun öğrencilerin eğitimin etkisiyle zaman içerisinde okuldaki spor etkinliklerine katılmasından kaynaklandığı düşünülebilir.

Bu çalışmada beslenme eğitimi süresinin iki ay ve eğitim sıklığının 15 günde bir ile sınırlı olması, eğitimin öğrencilerin beslenmealışkanlıklarıüzerindeistenilen etkiyi yapmadığını göstermiştir. Adölesan dönemde gençlerin ilgisini çekmek, konsantrasyonlarını sağlamak oldukça zordur. Bu dönemde beslenme eğitiminin etkin ve kalıcı olabilmesi için sürekliliğinin sağlanması, ilgi çekici, anlaşılabilir, eğlenceli olması gerekmektedir. Dolayısıyla eğitimlerin ders notları dışında, soru-cevap, grup tartışması, dramalar, oyunlar, gibi yöntemlerle daha etkili ve kalıcı hale getirilmesi sağlanmalıdır. Adölesan dönemde gençlerin izlenmesi, ailede ve okulda önerilen miktar ve türde besin ögelerini almaları için aileokul iş birliğinin sağlanması gerekmektedir. Yemek hizmeti sunan okullarm yemekhane ve kantinlerinde adölesanların büyüme ve gelişimini desteklemek ve sağlıklı beslenme alışkanlığı kazandırmak amaçlanmalı ve okul beslenme programlarının yaygınlaştırılarak, eğitimlerin daha uzun süreli, sık aralıklarla verilmesinin eğitimin kalıcılığıve davranışa dönüşmesi için gerekli olduğu unutulmamalıdır. Adölesan dönemde sağlıklı yaşam alışkanlıklarının kazanılması ileri de sağlıklı toplum oluşturabilmenin temel ilkesini oluşturacaktır.

Çıkar çatışması - Conflict of interest: Yazarlar çıkar çatışması olmadığını beyan ederler. - The authors declare that they have no conflict of interest.

\section{KAYNAKLAR}

1. T.C. Sağlık Bakanlığı. Türkiye Beslenme Rehberi (TÜBER). Sağlık Bakanlığı Yayınları, Ankara, 2015. Erişim adresi: http://dosyasb.saglik.gov.tr>10915,tuberturkiye-beslenme-rehberi pdf. Erişim tarihi: 20 Mayıs 2019.

2. Aksoydan E, Çakır N. Adölesanların beslenme alışkanlıkları, fiziksel aktivite düzeyleri ve vücut kütle indekslerinin değerlendirilmesi. Gülhane Tip Derg. 2011;53:264-70.

3. Yabancı Ayhan N. Adölesan beslenmesi. Özenoğlu A, editör. Beslenmenin Esasları ve Sağlığın Korunmasında Beslenme. Ankara: Hatiboğlu Yayınları; 2016. s.699-716.

4. Sabbağ Ç, Sürücüoğlu MS. İlköğretim öğrencilerine verilen beslenme eğitiminin beslenme tutum ve davranışlarına etkisinin değerlendirilmesi. Gıda Teknolojileri Elektronik Dergisi. 2011;6(3):1-13.

5. Yabancı N. Okul sağlığı ve beslenme programları. TAF Prev Med Bull. 2011;10(3):361-8.

6. Baltacı G, Ersoy G, Karaağaoğlu N, Derman O, Kanbur N. Ergenlerde Sağlıklı Beslenme ve Hareketli Yaşam. 1. Baskı. Ankara, Sağlık Bakanlığı Yayınları; 2008. s.29. Yayın No.:730. 
7. Öztürk M. Üniversitede eğitim-öğretim gören öğrencilerde Uluslararası Fiziksel Aktivite Anketinin geçerliliği ve güvenirliği ve fiziksel aktivite düzeylerinin belirlenmesi [Yüksek Lisans Tezi]. Hacettepe Üniversitesi Sağlık Bilimleri Enstitüsü. Ankara; 2005.

8. Genç A, Şener Ü, Karabacak H. Kadın ve erkek genç erişkinler arasında fiziksel aktivite ve yaşam kalitesi farklılıklarının araştırılması. Kocatepe Tıp Dergisi. 2011;12:145-50.

9. Türk M, Gürsoy ŞT, Ergin I. Kentsel bölgede lise birinci sinıf öğrencilerinin beslenme alışkanlıkları. Genel Tıp Derg. 2007;17(2):81-7.

10. Aslan NN, Yardımcı H, Özçelik AÖ. Üniversite sınavına hazırlanan öğrencilerin makro besin ögesi alımları ve antropometrik ölçümlerle ilişkisi. Erciyes Üniversitesi Sağlık Bilimleri Fakültesi Derg. 2007;4(1):39-48.

11. T.C. Sağlık Bakanlığı, Türkiye Beslenme ve Sağlık Araştırması 2010: Beslenme durumu ve alışkanlıklarının değerlendirilmesi sonuç raporu. Sağlık Bakanlığı Sağlık Araştırmaları Genel Müdürlüğü, Ankara, 2014. s.565. Yayin No.:931.

12. Baş M, Altan T, Dinçer D. Determination of dietary habits as a risk factor of cardiovascular heart disease in Turkish adolescents. Eur J Nutr. 2005;44(3):174-82.

13. Briggs M, Cockburn E, Rumbold PLS. Assessment of energy intake and energy expenditure of male adolescent academy-level soccer players during a competitive week. Nutrients. 2015;7:8392-401.

14. Dülger G, Şahan Y. Diyet lifinin özellikleri ve sağllk üzerindeki etkileri. Uludağ Üniversitesi Ziraat Fakültesi Dergisi. 2011;25(2):147-57.

15. Gümüş H, Bulduk S, Akdevelioğlu Y. Yetiştirme yurtlarında kalan adölesanların beslenme ve fiziksel aktivite durumlarının vücut kompozisyonları ile ilişkisinin saptanması. Uluslararası İnsan Bilimleri Dergisi. 2011;8(1):785-808.

16. Lopez-Sobaler AM, Aparicio A, Gonzalez-Rodriguez LG. Adequacy of usual vitamin and mineral intake in Spanish children and adolescents: ENALIA Study. Nutrients. 2017;9(2):131.

17. Yücel B. Sağlık çalışanlarının beslenme alışkanları ve beslenme bilgi düzeylerinin incelenmesi [Yüksek lisans tezi]. Başkent Üniversitesi Sağlık Bilimleri Enstitüsü, Ankara; 2015.

18. Viggiano A, Viggiano E, DiCostanzo A, Viggiano A, Andreozzi E, Romano I, et al. Kaledo, a board game for nutrition education of children and adolescents at school: Cluster randomized controlled trial of healthy lifestyle promotion. Eur J Pediatr. 2015;174(2):217-28.

19. Kayıhan G,ErsözG.15-18yaşgrubuadölesanlarda obezite tanısında ve vücut yağ yüzdesinin belirlenmesinde kullanılan farklı yöntemlerin karşılaştırılması. Türkiye Klinikleri J Sports Sci. 2009;1(2):107-16.

20. Vardar Yağlı N, Sağlam M, İnal İnce D. Akut koroner sendromlu olgularda fiziksel aktivite, yaşam kalitesi ve psikososyal fonksiyon arasındaki ilişki. Turk J PhysiotherRehabil. 2013;24(2):151-5.

21. Dmitruk A, Kunicka I, Popławska H. [Relationship between diet and physical activity level in adolescents from post-grammar schools]. Rocz Panstw Zakl Hig. 2016;67(1):37-44. Polish (abstract).

22. Tsioufis C, Kyvelou S, Tsiachris D. Relation between physical activity and blood pressure levels in young Greek adolescents: The Leontio Lyceum Study. Eur J Public Health. 2011;21(1):63-8. 